\title{
笛吹嘉一郎の職能と茶室の全体的把握のための基礎的研究 BASIC STUDIES FOR A GENERAL COMPREHENSION OF THE SKILLS AND THE TEA ROOMS OF KAICHIRO USUI
}

松本康隆*

Yasutaka MATSUMOTO

\begin{abstract}
Kaichiro USUI is a designer of modern tea rooms, and the some he designed for OKOCHI VILLA and Ichizo KOBAYASHI's SOKU-AN let us recognize importance in modern times. After World War II, he designed OMOTESENKE' branch office which is a base in Tokyo of OMOTESENKE, and enlarged OMOTESENKE residence in Kyoto. So he is also important as a Designer who present OMOTESENKE after the war. But, up to know, there has been no study about the whole life work of Kaichiro. The purpose of this paper is to settle the fundamental basements for the futures studies about him.

In this study, by first piecing out Kaichiro's texts, plans, and interviews with someone who related to him, we want to make synthesis of his skill as a Sukiya-shi. By listing up his architecture, we understood the where it spread in the different regions, and the approximate proportion of the tea rooms in his all work.
\end{abstract}

Keywords: Kaichiro USUI, Modern, Tea-room, SUKIYA-Daiku, Sukiya-shi 笛吹嘉一郎, 近代, 茶室, 数寄屋大工, 数寄屋師

\section{1. 研究の目的}

近代以降、利休の歴史的重要性が強調されるとともに、利休の直 系の子孫とされる表 (不審菴)、裹 (今日庵)、武者小路（官休庵） の三千家を中心とした近代的家元組織がそれぞれ構策、拡大してき た。そして、現在も茶道界において最も影響力のある流派はこの三 千家であると言えよう。その三千家の近代を代表する茶室の作り手 として、表千家では平井家や笛吹嘉一郎、裹千家では木村清兵衛、 武者小路千家では木津宗詮などを挙げることができる。このらち、 筆者は、現時点で確認できる木津宗詮の著作と建築作品をリスト化 して、その職能と茶室の全体的把㩧を試みた非1)。本稿では、笛吹嘉 一郎を対象にして、同様の考察を行う。

嘉一郎に関する先行研究としては、中村昌生『数寄の工匠』注 2) を挙げることが出来る。「中間報告」との断りはあるが、中村博士は この中で、近代から現在までの多くの「数寄の工匠」たちの系譜を 明らかにし、作品及び作風を研究、紹介している。嘉一郎はその「工 匠」、或いは「数寄屋大工」の一人として配置されている。中村博士 は、まず嘉一郎が平井家の流れをひく大工であることを明らかにし、 次に嘉一郎の独自性を考察している。そして嘉一郎の目標は「工匠 として独自な数寄屋師の立場を完成することに向けられていたに違 いない。としている。作品としては大河内山茌を取上げ、「数奇屋
造を基調とし、また数寄屋師ならではの柔軟な姿勢と技法が展開さ れている作品」と述べ、「工匠」或いは「数寄屋大工」の中の「数寄 屋師」という独自性を指摘している。

嘉一郎は、戦前には大河内山荘注 3) や小林一三の茶室注 4) など、 著名な数寄者の茶室を数多く手がけており、戦後には表千家の東京 出張所、京都不審帛の増築などを行っている注 5)。そして、中村博士 も触れているように、嘉一郎は自らを「数寄屋師」と規定していた。 なぜ嘉一郎は「数寄屋師」と称し茶室を建て続けたのか、具体的 な茶室を通して作風を読み取り、その作風からの解釈に重きを置い た若干の考察は既に行った注 ${ }^{6)}$ 。本稿では、嘉一郎に関する文献史料 や図面史料、及び関係する人々からの聞き取り調查を通じて、嘉一 郎の「数奇屋師」としての職能を考察する。次に、現時点で確認す ることができた嘉一郎による建築作品リストを作成し、引き続き職 能の考察と共に、地域的な分布や建築作品の全容を把握するための 基整的作業を行う。最後に、明らかにした職能および作品の全体像 から若干の考察を試みたい。

\section{2. 笛吹家について}

笛吹家の過去帳によると、表 1 のように嘉一郎より 3 代前の長八 まで確諗する事ができる。嘉一郎の実娘にあたる笛吹春子氏注 7)に 
よると、もとは東京の大工であったらしいが、数寄屋専門であった かどうかは定かではない。この長八か新七の代に関西に来たといわ れ、新七は柴田清七という人物の長男嘉三郎を養子に迎える注8)。乙 して嘉三郎の息子として生まれたのが嘉一郎である。嘉三郎は、表 千家出入りの「数寄屋師」注 9) として知られる平井家で働いていた が、その後独立したらしい。嘉一郎は嘉三郎の指導の下、「数寄屋師」 としての素養を身につけたようである注10)。

表 1 笛吹家の代々

\begin{tabular}{|c|c|}
\hline 名首 & 生没年 \\
\hline 長入 & $\sim 1857$ (安政4) \\
\hline 新七 & 1832(天保3) 1904(明治37) \\
\hline 虽三郎 & 1873(明治6) 1922(大正11) \\
\hline 憘二的 & 1898(明治31) 1969(昭和44) \\
\hline & 1928(昭和 3 ) 1990(平成2) \\
\hline
\end{tabular}

\section{3. 笛吹霖一郎の文献・図面史料とインタビュー 文献史料}

現時点で確認できた堂一郎による文章は、以下に挙げた「ご同慶 の至り」のみであり、嘉一郎が文章を書くことは殆どなかったと考 えられる。

「ご同慶の至り」の文章は昭和 34（1959）年 6 月 25 日の『建設 写真新聞』に、表千家増策工事竣工記事の中に揭載されたものであ る。ここで嘉一郎はまず「お茶のむつかしさは伝統に生きその道を 悟ることにあると思う」と茶道の立場を最初に述べ、次に茶道にお ける「外国の模做の入込ない湲しさ」を説いている。そして「茶室 建築」はその蕨しさが必要であり、当時の茶室建築を「近代建築の 進化とともにその厳しさのない自由な意図のもとに設計されている のが多いと批判している。表千家增策工事に関しては、「一部鉄筋 コンクリート建物を挟む防火構造」としなければならなかったが、 苦心の末「見苦しい線を出さず美事に竣工した」と述べている。

嘉一郎は、ここで茶道の「峳しさ」を説いているが、それは「自 由」と対置された概念であることがわかる。そして、作品に実現さ せる「㜄しさ」とは、鉄筋コンクリートなどの「見苦しい線」を出 さないことであると捉えることができる。

\section{图面史料}

図面を中心とした史料は笛吹春子氏、及び田尻晶英氏注 11 にによっ て所藏されている。現時点で笛吹家に 1182 点、田尻家には 5 点、 計 1187 点の図面史料の存在が確認できた注 12 )。

図面史料を見度すと、設計している対象は住宅、茶室、庭などが 見られる。このうち、庭には露地の外腰掛、門、戸、飛石、踞、 石灯籠、樹木などの表記が見られるが、石や樹木の配置などに寸法 の表記は見られない。彩色などもなく、シングルラインで描かれて いるなど、木津宗詮図面と比較しても注13)、庭の設計図としては簡 略的なものと言うことができる。また、木津宗詮図面にみられるよ うな、石灯籠のデザインなども見られない。つまり、茶の施設の全 体的な計画を視野に入れているとはいえ、やはり大工仕事を主体と した設計であったということが出来る。

\section{インタビュー}

春子氏からの聞き取り調查によると、施主の紹介について、西尾
真、生方貴一、徳禅寺和尚などに大変お世話になったとのことであ った注 14)。今後、遺構の調査と共に、施主の紹介についての寒証作 業が必要である。また、施主の獲得については、上記の紹介だけで はなく、小林一三関保の茶室や大河内傳次郎の山荘など、知名度が ありかつメディアに載る作品を手がけたことなどもプラスに働いた と思われる。

さらに、自ら茶道の稭古を行い壮 15 、自会の茶事・茶会への招待、 他会への参加や世話を通じて雇客が広がり、繋がりも維持されてい る点も大きいと思われる。中村博士は、「晚年の氏は、作陶に興じた り、金を䀣けては客を呼んで楽しむ日が多かった。と、晚年の茶会 について述べているが、春子氏が母親（嘉一郎夫人）から開くとこ ろによると、嘉一郎は戦前から自邸茶室「無孔庵」で茶会を開いて いたらしい注16)。戦中の强制㻋開によって、自邱及び茶室「無孔庆」 は取り䘫され、以後、自邸での茶会は開けなくなったが、大徳寺玉 林院での月釜茶会「南明会」注17) のメンバーに戦前から加わってい たらしく、定期的に茶会を催していたようである。

つまり、嘉一郎にとって茶会は、晚年の心の余裕が生み出したも のではなく、施主の獲得にとっても初期の頃から欠かせないもので あったと考えられる。そして、それだけでなく、先に述べたような 茶道の「厳しさ」を追求することにこそ、本来の目的があったよう に思われる。

\section{4. 笛吹嘉一郎の建築作品 \\ 建策作品一筧}

これまで見てきた図面史料に加え、笛吹春子氏、吉村龍三氏注 18)、 田尻晶英氏をはじめ、関保する人々への聞き取り、及びその他文献 資料などから、現時点で物件名が明らかで笛吹嘉一郎作であると確 定出来たもの、或いはその可能性が高いものを表 2 の一覧にまとめ た。一覽には、まず年代が明らかなものを、先に年代順に並べ、続 いて年代が不明なものをアイウエオ順に並べた。また、前者の年代 順の一覧には、春子氏の闑き取り調查から得た情報から、自宅住所 の変遷を組み込んだ。住 19)

\section{建筑作品の地域分布}

物件名が明らかで作品の年代が判明したものは 109 件、建築年代 がわからないものは 58 件確認することができた。このリストの中 から物件の所在を都道府県別に数の多い順に見ると、京都が 30 件 で最も多く、東京の 20 件が次に続く。以下順に大阪（19 件）、山口 (15 件)、兵庫 (12 件)、広島 (10 件)、福岡 (9 件)、和歌山 (6 件)、三重・岡山（各 3 件）、静岡 (2 件)、北海道・青森・福井・岐 阜・奈良・香川・佐賀・大分・中国・インド（各 1 件）となってい る。地域が不明な物件は 28 件である。

やはり京都を中心に京阪神の作品が多いが、東京や山口、広島、 福岡のものも多い。その他、数は少ないが、北海道から九州まで、 全国的に作品を手がけていること、戦時下の旧外地や、戦後の大使 館における茶室も手がけていたことがわかった。

\section{作品リストからみる設計内容}

設計の内容をみると、167 件中、これも判明する限りであるが、 住宅は 31 件、茶室は 146 件、庭は 55 件、商業施設は 6 件となる。 


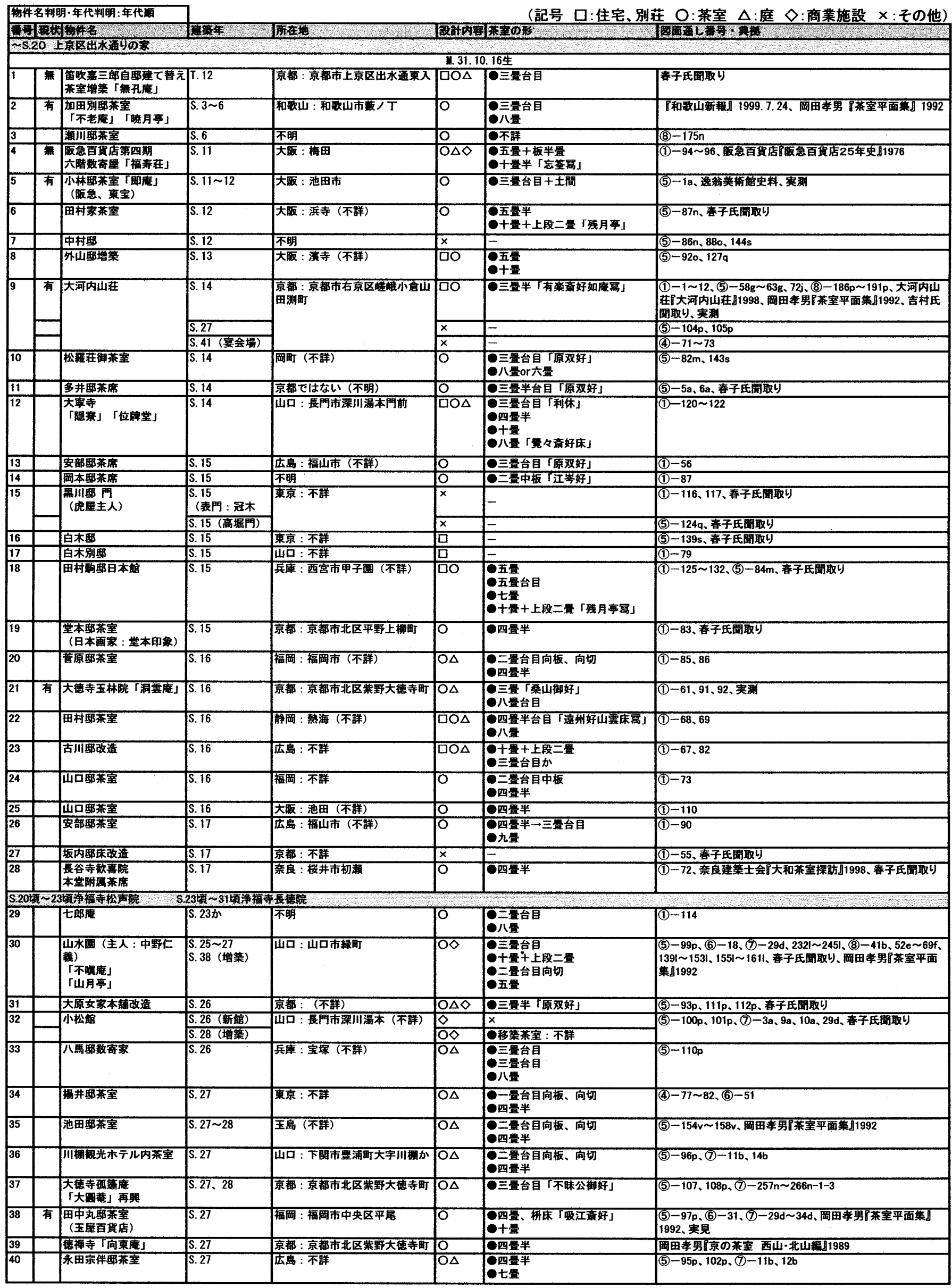




\begin{tabular}{|c|c|c|c|c|c|c|c|}
\hline 41 & & 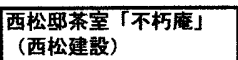 & $\$ .27$ & 瑓京：桷町（不詳） & O & 三量中板 & 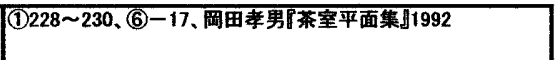 \\
\hline 4 & & 原田酣莱室 & 5.27 & 不明 & $\mathrm{O \Delta}$ & O三畳半 「原双好了 & 5 \\
\hline 43 & & 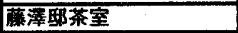 & 5.27 & 大俽町 (広島か) & OA & 三量台目 & (5) $-98 \mathrm{p},(7)-11 \mathrm{~b}$ \\
\hline 44 & & 山根野「花醉掼」 & 5.27 & 広島: 三原 (不䛨) & $\overline{O \Delta}$ & 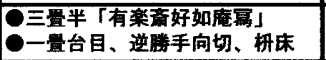 & 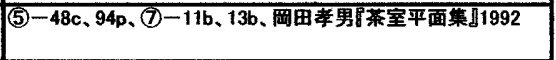 \\
\hline \multirow[t]{2}{*}{45} & \multirow[t]{2}{*}{ 有 } & \multirow[t]{2}{*}{ 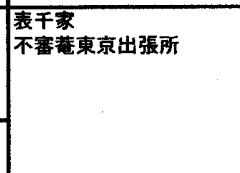 } & 5. $28 \sim 30$ & \multirow[t]{2}{*}{ 宩京：千代田区幽町 } & $\square O \Delta$ & 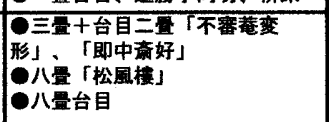 & \multirow[t]{2}{*}{ 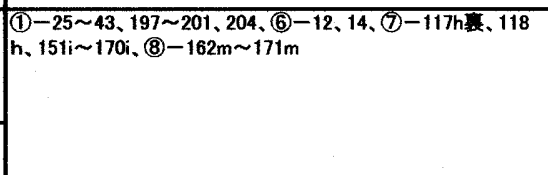 } \\
\hline & & & $\begin{array}{l}\text { S. 44 45 } \\
\text { (移築及模梾替) }\end{array}$ & & 00 & $\theta+\frac{9}{9}$ & \\
\hline 46 & & 鈴木的增築 & S. 28 & 山口：辰門市東深川正明市 & $x$ & - & $(1)-22$ \\
\hline 47 & & 野村䋅券ビル「得庵」 & 5.28 & 菄京 : 中央区日本橎留町 & $\mathrm{O}$ & 四量半 & 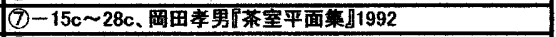 \\
\hline 48 & & 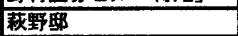 & 5.28 & 兵庫：媉路 (不詳) & $\square$ & - & $77-29 d, 35 d, 36 d$ \\
\hline 49 & & 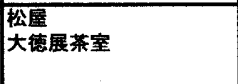 & S.28 & 菓京: 不群 & $\overline{\mathrm{O} \Delta}$ & 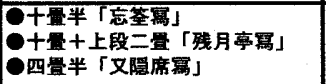 & $(5)-159 v \sim 163 w,(8)-37 e \sim 42 e$ \\
\hline 50 & & 唋屋 新館 & 5.28 & 山口 : 山口市湯田温泉 & $\overline{\mathrm{O} \Delta \Delta}$ & 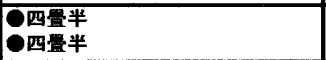 & $77-3 a, 5 a, 6 a$ \\
\hline 51 & & 山本邱茶室 & 5.28 & 庆島: 不詳 & $\bar{O}$ & E三量台目「原奴好」 & $77-3 a, 7 a, 8 a$ \\
\hline 52 & & 初波奈畉来室 & S. 29 & 宩京：不詳 & $O \Delta$ & 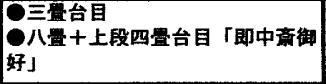 & (5)-54d、128r 133r、(尹)-55g 57g、春子氏聞取り \\
\hline 53 & 無 & 㕍田家東影莱室 & 5.29 & 大阪 : 大腵市都島区網島町 & O & 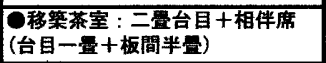 & 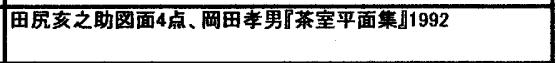 \\
\hline 54 & & 有川䧉来窒 & 5.29 & 不明 & OA & 四专半 & 5 \\
\hline 55 & & 守分焣 & 5.29 & 岡山 : 岡山市 (不詳) & $\square O \Delta$ & 四盢半 & $(5)-164 x, 165 x, 177$ aa $\sim 179 a a,(7)-3 a, 43 f \sim 53 f$ \\
\hline 56 & & 市橎的 & 5.30 & 福井 : 不群 & $\square O \Delta$ & 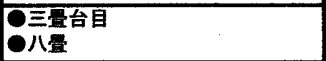 & (5)-106p、(8)-171j 185j、春子氏聞取り \\
\hline 57 & & 金菻幹夫郎莱席 & 5.30 & 岡山：倉敖市連島町（不鲜） & $\overline{O \Delta}$ & 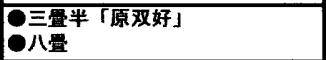 & $(5)-180 b b .(7)-149 h \overline{1}, 274 p, 275 p$ \\
\hline 5.23 & 值 $\sim 3$ & 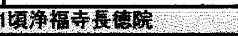 & S.31垻 $\sim 41$ 垻 & 西毠的 & & & \\
\hline 58 & & 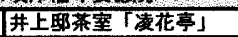 & S. 31 & 大腵 : 池田市 $($ 不群 $)$ & $O \Delta$ & 四畺半 & (4)-75,剛田孝男『来室平面集】1992 \\
\hline 59 & & 吉比為之助酣《間 & 5.31 & 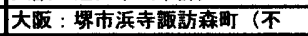 & 0 & E三睤台自向板、逆勝手向切 & (5) $-40 \mathrm{c},(6)-33 \sim 35,45,52,(7)-95 \mathrm{~h}$ 党,, $97 \mathrm{~h}$ 咅 \\
\hline 60 & & 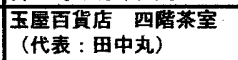 & 5.31 & 福㽢 : 不詳 & O & 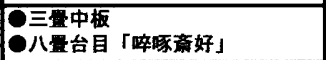 & 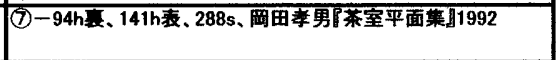 \\
\hline 61 & & 䓀田神社移藥䒺笽改造 & S. 31 & 京都：京都市左京区吉田神薬岡 & O & 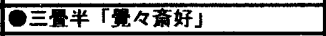 & $52 \mathrm{~s}$ \\
\hline 62 & & 福寺䒚室 & 5.32 & & 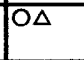 & 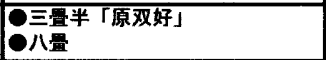 & (5)-70j黑.(8)-3 \\
\hline 63 & 無 & 加田畛茶室 & S. $32 \sim 35$ & 和歌山 : 和歌山市卜半町 & $\overline{\mathrm{O} \Delta}$ & 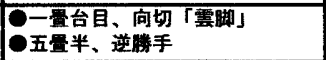 & (7)-267o 2730，(8)-1820 1850，加田文店氏聞取り \\
\hline 64 & & 阊湯的策至 & 5.32 & 湅京: 不詳 & $\mathrm{O \Delta}$ & 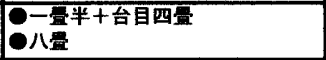 & 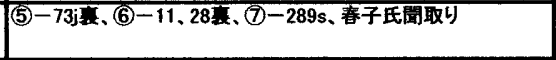 \\
\hline 65 & & 岸信介的案室 & 5.32 & 軍京 : 涉谷区南平台町 & $\overline{O \Delta}$ & 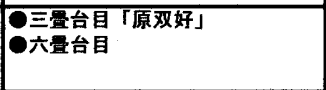 & 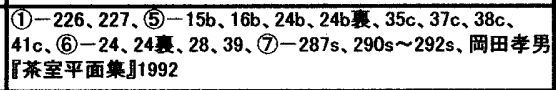 \\
\hline 66 & & 诚辺郳茶室 & 5.32 & 香川：三木町 (不群) & $\mathrm{O}$ & 四量半、向切 & $87-282 r \sim 286 r$ \\
\hline 67 & & 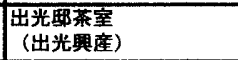 & 5.33 & 軍京 : 不磰 & $\overline{O \Delta}$ & D二䨌台自 & 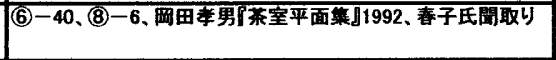 \\
\hline 68 & & 上田厤菜室 & 5.33 & 和取山:不群 & O & 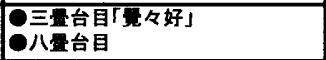 & $(3)-2 \frac{1}{1},(5)-23 b, 70 j,(6)-10,25$ \\
\hline 69 & & 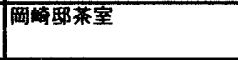 & $5.31 \sim 33$ & 楅岡 : 北九州市八幅 (不濓) & $\overline{0}$ & $\begin{array}{l}\text { 三量中板 } \\
\text { 公量 }\end{array}$ & 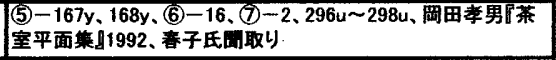 \\
\hline 70 & 有 & \begin{tabular}{|l} 
俵千家 \\
不蕃巷增築
\end{tabular} & S.33 (增要) & 京都 : 上京区寺之内通堀川東入 & O & $\begin{array}{l}\text { 量 } \\
\text { e+量 }\end{array}$ & $\begin{array}{l}(1)-133 \sim 140,143 \sim 196,(3)-63,(5)-57 f, 781,811,184 \mathrm{ee} \\
(6)-42,48,49,(8)-220 \mathrm{k}, 224 \mathrm{k},(8)-76 \mathrm{~g}, 1,106 \mathrm{j} \sim 122 \mathrm{j}\end{array}$ \\
\hline & & & S. 36 (改造) & & $x$ & - & \\
\hline & 有 & & S. 41 (表門) & & $x$ & - & \\
\hline 71 & & 左橋宗回传頼茶室 & 5.33 & 不明 & $\mathrm{O}$ & 四䱏半 & $(8)-10$ \\
\hline 72 & & 状原晒 & S. 33 & 不明 & $\mathrm{O}$ & 六量 & $8-5$ \\
\hline 73 & & $\begin{array}{l}\text { 竹中部 } \\
\text { (竹中工務店) }\end{array}$ & 5.33 (乘室) & 共庫 : 神市 (不群) & O & 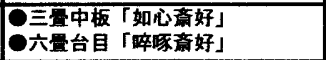 & 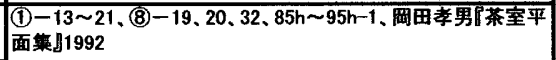 \\
\hline & & & S.41(仏間) & & $\overline{\mathrm{O} \Delta}$ & O仏間：入目 & \\
\hline 74 & & 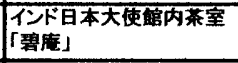 & 5.34 & イント:ニューデリー & O & $\begin{array}{l}\text { 台貝四量向切 } \\
\text { 量 }\end{array}$ & 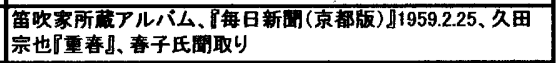 \\
\hline 75 & & 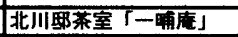 & 5.34 & 菓京:不群 & $\overline{O \Delta}$ & E三量台目 & 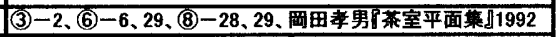 \\
\hline 76 & & 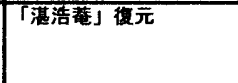 & S. $34 \sim 38$ & 福嗍：博多区干代 & $\overline{O \Delta}$ & 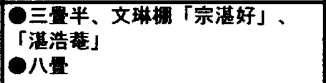 & $\begin{array}{l}(1)-58,205 \sim 225,(5)-171 \mathrm{y},(6)-4,32,36,3815,(8)-31, \\
37 \mathrm{a} \sim 39 \mathrm{a}, 70 \mathrm{~g} \sim 74 \mathrm{~g}, 76 \mathrm{~g} \sim 84 \mathrm{~g}\end{array}$ \\
\hline 77 & & 屈来寺茶窒 & 5.34 & 不明 & $\overline{\mathrm{O} \Delta}$ & 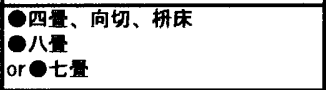 & $(8)-30,36$ \\
\hline 78 & & 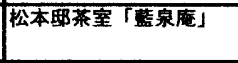 & 5.34 & 庆島: 福山市(不群) & $\mathrm{O \Delta}$ & $\begin{array}{l}\text { Q三冨台目 } \\
\text { の量 }\end{array}$ & 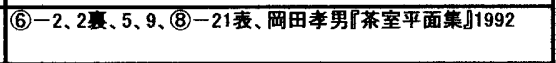 \\
\hline 79 & & 奥村㫜增策 & S. $35 \sim 36$ & 不明 & $\bar{\square}$ & - & $\begin{array}{l}(8-186 \mathrm{k} \sim 219 k, 221 \mathrm{k} \sim 223 k, 225 \mathrm{k} \sim 231 \mathrm{k}, 293 \mathrm{t} \sim 295 \mathrm{t},(8) \\
-8,9,14 \sim 16,25\end{array}$ \\
\hline 80 & 取止 & 成吉鄞菜室 & $5.35 \sim 36$ & 厘京: 不詳 & $\overline{\mathrm{O} \Delta}$ & 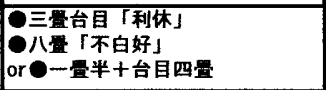 & $(4)-32,34,(8)-23$ \\
\hline 81 & & 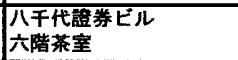 & S. $35 \sim 37$ & 厘京: 不詳 & $\overline{\mathrm{O} \Delta}$ & 四冝 & 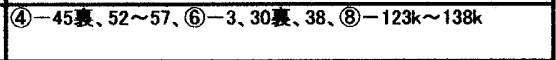 \\
\hline 82 & & 摩的茶耊 & 5.36 & 京都 : 山科 (不群) & $\overline{\mathrm{O} \Delta}$ & 西畏 & (4)-44.45、春子氏闌取り \\
\hline 83 & & 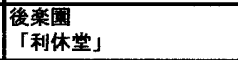 & 5.36 & 岡山 : 岡山市後麥固 & $O \Delta$ & 一五骨半+上段+内漣「利休堂」 & $(6-21,50,(8)-246 \mathrm{~m} \sim 256 \mathrm{~m},(8)-22,27$ \\
\hline 84 & & 舒泉院莱窒 & S. 36 & $\begin{array}{l}\text { 八戸市(青森: 八戸市新井田字 } \\
\text { 寺ノ上が) }\end{array}$ & o & 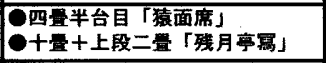 & (4) $-67 \sim 70$ \\
\hline 85 & 有 & 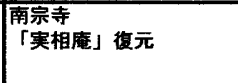 & S. 36 & 大阪：琾市南旅町菓 & $\overline{\mathrm{O} \Delta}$ & 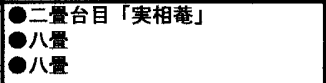 & (4) $-35 \sim 40,(8)-96 i \sim 105 i$ \\
\hline
\end{tabular}




\begin{tabular}{|c|c|c|c|c|c|c|c|}
\hline 86 & & 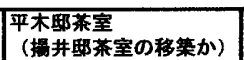 & 5.36 & 庽京：世田谷区世田谷 & $\mathrm{O \Delta}$ & $\begin{array}{l}\text { O-畳台自向板、向切 } \\
\text { e四半 }\end{array}$ & $(7)-276 q \sim 281 q,(8)-2$ \\
\hline 87 & & 光明寺境内莱室 & $5.37 \sim 38$ & 京都 : 長岡京市粟生西㷛八内 & $O \Delta$ & 一六量台目「卒䀦㫷好」 & (4) $-49,50,(6)-23,(8)-12,17,172 n$ \\
\hline 88 & & 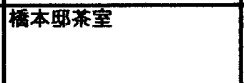 & $5.37 \sim 39$ & 和歌山：和歌山市（不群） & $O \Delta$ & 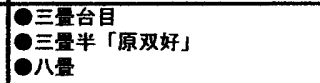 & (1) $-239,240$, (4)-42, (8) $-7,18,44 \mathrm{c} \sim 47 \mathrm{~T}, 48 \mathrm{c}$ \\
\hline \multirow[t]{2}{*}{8} & & \multirow[t]{2}{*}{ 分桓的䒩垔 } & 5.37 & \multirow[t]{2}{*}{ 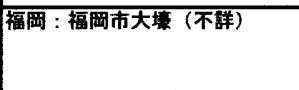 } & To & $\begin{array}{l}\text { 管量台目 } \\
\text { 量 }\end{array}$ & \multirow[t]{2}{*}{$(1)-231 \sim 233,(8)-26,40 b \sim 43 b, 1541$} \\
\hline & & & 5.51 & & $x$ & - & \\
\hline 90 & 有 & 笛吹諪一郎自的 & 5.38 & 京都 : 京都市北区䇣野下㕖山町 & $\square O \Delta$ & $\begin{array}{l}\text { 8一冨台自中板、向伆 } \\
\text { ○六台目 }\end{array}$ & $(1)-234 \sim 238,(8)-75 g$ \\
\hline 91 & & 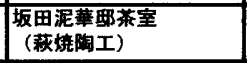 & $5.38 \sim 39$ & 山口: 長門市深川潈本 & $\mathrm{O \Delta}$ & \begin{tabular}{|l|l} 
三量台目 \\
目鲾半 \\
\end{tabular} & $\longdiv { 4 4 - 5 8 \sim 6 2 }$ \\
\hline 92 & & 虎屋ビル二陼菜窒 & 5.38 & 瑓京:不群 & o & 万八曺半 & (4) $-41,(8)-33 \sim 35$ \\
\hline 93 & & 吉水舅莱室 (吉水宗白) & 5.38 & 景都 : 四媒大宫 (不詳) & o & 三三鲾台目 & 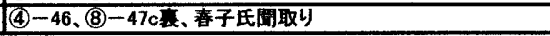 \\
\hline \multicolumn{8}{|c|}{ 繁野自自 } \\
\hline 94 & & 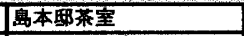 & 5.39 & 和歌山：和歌山市（不詳） & OQ & O三量台目[少薏好] & (4)-47, (6)-23咅、43, (8)-1 \\
\hline 95 & 有 & 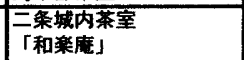 & 5.39 & $\begin{array}{l}\text { 景都 : 京都市中京区二条通堀III } \\
\text { 西入三城町 }\end{array}$ & o & 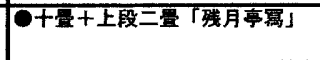 & (6)-1, (8)-24、吉村氏閶取り \\
\hline 96 & & 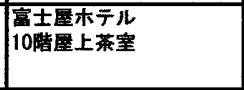 & 5.39 & 静凮：熱海（不詳） & $O \Delta$ & 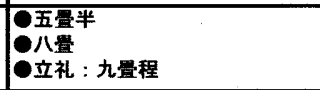 & (4) $-65,66$ \\
\hline 97 & & 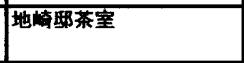 & 5.40 & 北海道：机愰市（不詳） & $\overline{O \Delta}$ & \begin{tabular}{|l} 
四瞢半台目 \\
公
\end{tabular} & (8)-49d 51d \\
\hline 98 & & 菓光寺杂室 & 5.40 & 京都：京都市上京区北复 & $\mathrm{O}$ & 四疊半 & (4)－48、春子氏闻取ら \\
\hline 99 & & 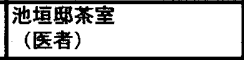 & 5.41 & $\begin{array}{l}\text { 景都：京都市中京区新町通鑸小 } \\
\text { 路上る百足星町 }\end{array}$ & O & 五畺 & (4)－43、春子氏闻取り \\
\hline 100 & & 後藤要久䭪茶空 & $\widehat{5.41 \sim 43}$ & 伎阜：枝官市中新町 & $\mathrm{O \Delta}$ & 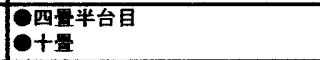 & $(1)-65,(2)-1 \sim 21,25 \sim 44$ \\
\hline 101 & & 平岡基吉的䒺席 & $5.41 \sim 42$ & 静岡：清水市（不詳） & $\mathrm{O} \Delta$ & 台目三㽬中板、汧床「宗全好」 & (4)-4 11、春子氏聞取り \\
\hline 102 & & 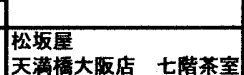 & $\frac{5.53 \text { (新席) }}{S .41}$ & 大阪：大阪市中央区天渶播京町 & $\begin{array}{l}O \\
O \Delta\end{array}$ & 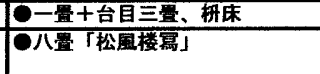 & (4)-13 22 \\
\hline 103 & & 杪喜底 玄関正面壁作替 & S. 41 & 景都 : 乙訓郡大山崎町龍光 & $x$ & - & $(1)-141,142$ \\
\hline 104 & & \begin{tabular}{|l} 
光悦寺茶室 \\
(住㙏 : 山下)
\end{tabular} & 5.42 & 景都 : 北区鷹審光㟋町 & $O \Delta$ & 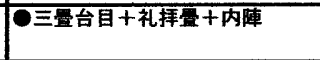 & (4) $-1 \sim 3,(6)-7,8,13$ 㐮, 26, 44 \\
\hline 105 & 有 & 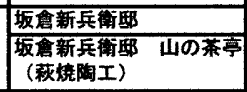 & \begin{tabular}{|l} 
不明 \\
S. 42 \\
\end{tabular} & 山口: 長門市深川湯本 & $\frac{\overline{O O \Delta}}{\mathrm{O} \triangle}$ & 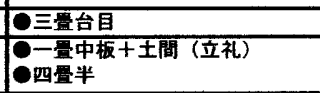 & 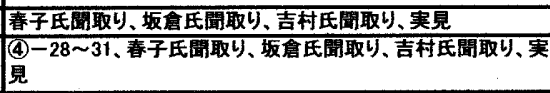 \\
\hline 106 & & 角屋的茶室中閜 & 5.42 & $\begin{array}{l}\text { 京都 : 京都市下京区西新屋敷場 } \\
\text { 屋町 }\end{array}$ & $x$ & - & (4)-63,64 \\
\hline 107 & & 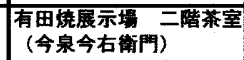 & 5.43 & 佈䐝：不群 & o & 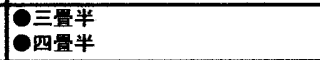 & (4)-23 27、春子氏聞取り \\
\hline 108 & & 岡崎酣 池辺紊 & 5.43 & 福岡 : 北九州 (不群) & to & 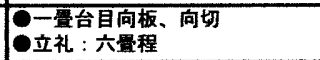 & (2)-22 24 \\
\hline \multirow[t]{2}{*}{109} & \multirow{2}{*}{\multicolumn{2}{|c|}{$\begin{array}{l}\text { 竹中烸 } \\
\text { (竹中工務店) }\end{array}$}} & $\begin{array}{l}\text { S. 43 44（菜 } \\
\text { 室) }\end{array}$ & \multirow[t]{2}{*}{ 兵庫 : 芦屋 (不詳) } & $\mathrm{O \Delta}$ & \begin{tabular}{|l|l|} 
三量台自 \\
○鱼「松国楼」 \\
\end{tabular} & \multirow[t]{2}{*}{ (2)-45 59, (3)-69 } \\
\hline & & & S.44 (崖切埸) & & $x$ & & \\
\hline
\end{tabular}

\begin{tabular}{|c|c|c|c|c|c|c|}
\hline 鳘量 & 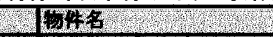 & 遇築年 & 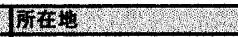 & 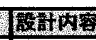 & क्तिका & 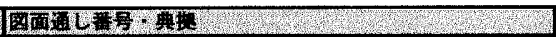 \\
\hline 1 & 戥田焣 & 不明 & 東京: 不詳 & 0 & 三三黄中板 & 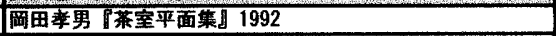 \\
\hline 2 & 安部砳 & 不明 & 庴庫 : 芦屋 (不詳) & o & 四瞢半 & 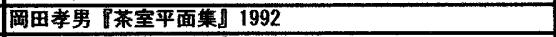 \\
\hline 3 & 安部的 & 不明 & 庆島: 福山 (不群) & o & 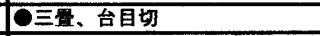 & 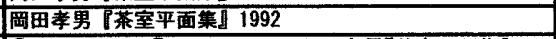 \\
\hline 4 & $\begin{array}{l}\text { 石䨩酣茶室 } \\
\text { (ブリジスン) }\end{array}$ & 不明 & 福阅：久留米市（不詳） & O & 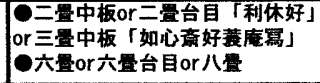 & 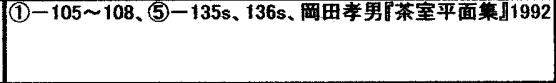 \\
\hline 5 & 䨱烟䵝来室改造 & 不明 & 京都: 不詳 & O & 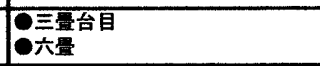 & (5)-85m、春子氏聞取り \\
\hline 6 & 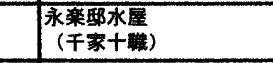 & 不明 & 京都: 不詳 & $x$ & - & (6)-42衰 \\
\hline 7 & 大谷的 樌月台 & 不明 & 山口: 長門市深川渴本 & To & 三量半「原双」 & (5) $-118 \mathrm{q}, 137 \mathrm{~s}$ \\
\hline 8 & 岡本的 垡泻改造 & 不明 & 和歌山: 不詳 & To & ○八量十上段二量「残月㗐了 & (1)-60 \\
\hline 9 & 神田的除庶 & 不明 & 山口: 楖井 (不群) & To & 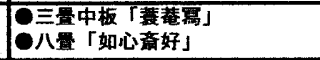 & $5-148 \mathrm{t}$ \\
\hline 10 & $\begin{array}{l}\text { 京都女学校同空会館 } \\
\text { 原上菜 }\end{array}$ & 不明 & 京都 : 菄山七条 (不詳) & 0 & 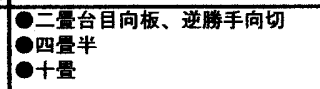 & (5)-142s、春子氏䦥取り \\
\hline 11 & \begin{tabular}{|l} 
小西畉改籍 \\
(小西酒造か)
\end{tabular} & 不明 & 娦庫 : 伊丹 (不詳) & Do & 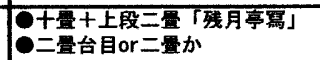 & $5-115 q$ \\
\hline 12 & 小西的 & 不明 & 庴庫：伊丹(不詳) & To & -一鲾台自、向切逆勝手 & 岡田素男『窒平面集』1992 \\
\hline 13 & 羭原温泉 & 还明 & 拉重 : 久居市样原町 & $\theta$ & - & (1)-97 101、(5)-3a、春子氏聞取り \\
\hline & & 不明 (清要徍) & & $\Delta$ & - & (5) $-116 q .117 q$ \\
\hline 14 & 坂野䵝 & 不明 & 岃口: 不詳 & o & 㭅量至目 & 岡田毒男菜室平面集其1992 \\
\hline 15 & 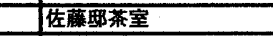 & 不明 & 大分：別府 (不詳) & to & 四異向板、向切「遠州好需」 & $(1)-112$ \\
\hline 16 & 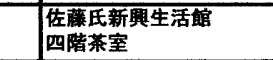 & 不明 & 不明 & To & $\begin{array}{l}\text { 四量半 } \\
\text { 量 }\end{array}$ & (1) -113 \\
\hline 17 & 自笑庫 & 不明 & 大服 : 泉大津 (不詳) & o & 四畺平 & 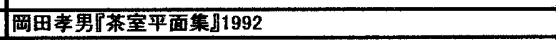 \\
\hline 18 & 碩照寺改策 & 不明 & 京都 : 四条 (不詳) & प0 & 六量 & (5)-123q、春子氏䦚取り \\
\hline 19 & 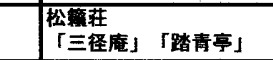 & 不明 & 天阪：不劷 & O & 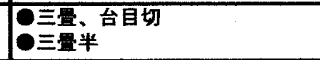 & 岡田孝男『菜室平面菒】1992 \\
\hline 20 & $\begin{array}{l}\text { 白开平七酣 } \\
\text { (㣮工) }\end{array}$ & 不明 & 不明 & $\square 0$ & 四骨半 & $(5)-74 j .119 q, 121 q$ \\
\hline 21 & 百井的 & 不明 & 庴庫：伊丹 (不詳) & To & 四畳半 & 犅田军男『菜室平面集』1992 \\
\hline 22 & 白百期案咅 & 不明 & 山口 : 字部市 (不詳) & o & e三畳中板 & $6-20$ \\
\hline 23 & 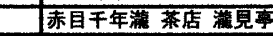 & 可不明 & 撞重: 赤目 (不詳) & D০ & 四量平台目、壁床 & (1) $-70,71$ \\
\hline 24 & 暗昧堂 & 不明 & 不明 & $x$ & - & $\frac{5}{(5)-152 t}$ \\
\hline
\end{tabular}




\begin{tabular}{|c|c|c|c|c|c|c|}
\hline 25 & 大同公目乘室 & 不间 & 中国：新景（不詳） & 0 & 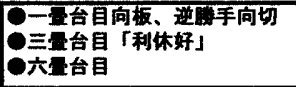 & (5)-4a、春子氏间取り \\
\hline 26 & 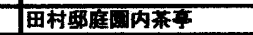 & 不明 & 不明 & O & 厽自五量，向切 & (5) $-140 \mathrm{~s}$ \\
\hline 27 & 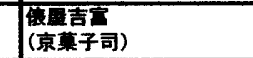 & 不再 & 景䧽:今出川耊町上ル & $\bar{O}$ & O不样 & 喜子氏间取り \\
\hline 28 & 丹羽阷 & 不明 & 京都:不郭 & $\overline{0}$ & 西量平 & 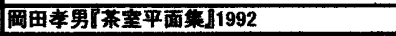 \\
\hline 29 & 外山的手洗所 & 不明 & 大陙：婐市源寺（不样） & $x$ & - & (1)－62、喜子氏间取り \\
\hline 30 & 永井期改迢 & 不明 & 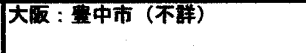 & 00 & 四䱏 & $(1)-115,(5)-141 \mathrm{~s}, 146 \mathrm{~s}, 147 \mathrm{~s}$ \\
\hline 32 & 中村㓰萧耋 & 不明 & 不明 & 0 & 大盍台目 & $11-93$ \\
\hline 33 & 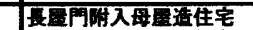 & 不明 & 不明 & 口 & $x$ & (1) -50 \\
\hline 34 & 南螎院菜害 & 不明 & $\begin{array}{l}\text { 不奛 (京都: 京都市左京区南禅 } \\
\text { 寺祖地町か) }\end{array}$ & $\bar{O}$ & 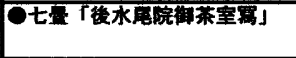 & $(5)-120 q$ \\
\hline 35 & 西尾的获舟了 & $\begin{array}{l}\text { 不盟(嘉一郎35 } \\
\text { 地の煩) }\end{array}$ & 京都 : 京都市北区小山東大野时 & $\overline{00}$ & 三自台目 & 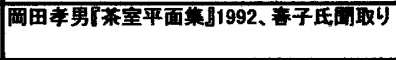 \\
\hline 36 & $\begin{array}{l}\text { 西而住舟的 } \\
\text { (画家) }\end{array}$ & 不明 & 不明 & DOA & $\begin{array}{l}\text { 四重、抍休 } \\
\text { 八量 }\end{array}$ & (1) -80 \\
\hline 37 & 西垣的 & 不明 & 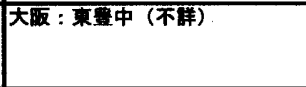 & प0 & 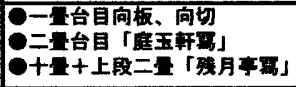 & $(1)-102 \sim 104$ \\
\hline 38 & 林垤 & 不明 & 京都：不群 & 0 & O三羊半 & 岡田孝男莱室平面賲]1992 \\
\hline 39 & 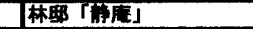 & 不明 & 京被 : 不群 & 0 & 三至台目 & 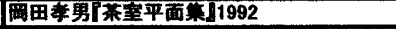 \\
\hline 40 & 原田禺 & 不明 & 大级：事曋中 & $\mathrm{O}$ & 四豆、汧床 & (1)-76,77 \\
\hline 41 & 東重中住宅地二六号地 & 不明 & 大服：東霬中 & $\square$ & 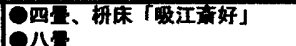 & $(1)-75$ \\
\hline 42 & 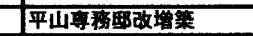 & 不明 & 果京：武形垔市吉祥寺 & 口 & - & (1) -23 \\
\hline 43 & 福田別㿟莱室 & S.20以前 & 大攵：不群 & $\mathrm{O}$ & ○三台台目「原双好」 & 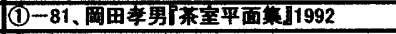 \\
\hline 44 & 人步 & 不明 & 不明 & $\square 0$ & $\begin{array}{l}\text { 三量台目 } \\
\text { 九量 }\end{array}$ & (5) $-113 q, 122 q, 125 q$ \\
\hline 45 & 松满氏庶 & 不明 & 宩京: 不解 & $x$ & - & $(5)-43 c$ \\
\hline 46 & 宮的 & 不明 & 広里：不群 & 0 & 三丨严中板 & 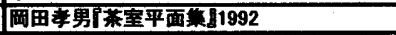 \\
\hline 47 & 森的 & 不明 & 兵庫 : 䒠重 (不群) & $\mathrm{O}$ & Q三百台目 & 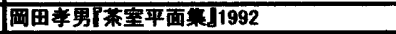 \\
\hline 48 & 森下的秉室 & 不明 & 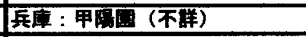 & $\mathrm{O}$ & 三三星中板 & 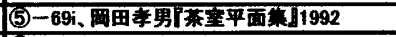 \\
\hline 49 & 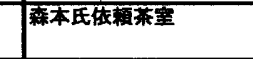 & 不明 & 三曋：伊嘪(不群) & 0 & $\begin{array}{l}\text { 四筁半台目 } \\
\text { 量 }\end{array}$ & $8)-4$ \\
\hline 50 & 山口耶 & 尔明 & 大原：大医市中央区淡路畹 & $\square$ & - & (5) $-134 \mathrm{~s}, 138 \mathrm{~s}$ \\
\hline 51 & 山口布 & 不明 & 不明 & $x$ & - & $(5)-43 c$ \\
\hline 52 & 山口酣莱窒 & 不明 (S. 33以 & 兩衣 (不样) & $\mathrm{O}$ & 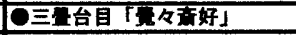 & (6) $-27,41$ \\
\hline 53 & 山口郳莱席 & 不明 & 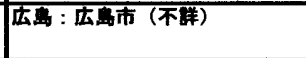 & 0 & $\begin{array}{l}\text { 三主台自 } \\
\text { 八量 }\end{array}$ & 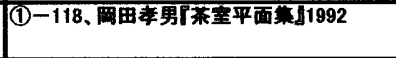 \\
\hline 55 & 完 山口重莱室改适 & 不明 & 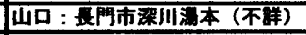 & 0 & 四冝台自 & (4)-51 \\
\hline 56 & 山中酣 & 不明 & 兵庫 : 伊丹(不释) & DO & 金素 & $(1-123,124$ \\
\hline 57 & 横田昰 & 不明 & 果京: 不群 & $\square 0$ & B三 & (1) $-88,89$ \\
\hline 58 & 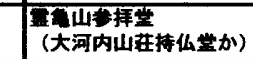 & 不明 & 京都:京都市右京区鹤か & $\bar{x}$ & - & $(5)-64 h, 65 h, 83 m, 150 t$ \\
\hline
\end{tabular}

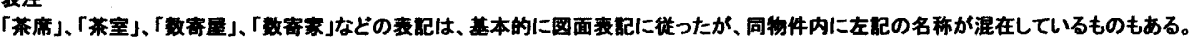

「取止」は图面上に「取止め」などの纪入が見られ、实竞に至らなかったと考えられるものを示す。

典拠の性格上、茶室の件数が若干多い傾向があるが注 20)、物件単位 の図面史料が充実しているものも多く、先に述べたように建物の図 面表記に比へ庭の表記は比較的简単なものであることなとかか、住 宅や庭の割合はそれほど增えないと予想される。つまり、嘉一郎は 住宅、茶室、庭、商業施設などの設計も行っていたが、茶室設計の 専門性が高いと言うことが出来よう。

\section{「好み」と「写し」}

他のジャンルの建築と比較すると、「好み」や「写し」の概念は、 茶室らしい特街として挙げることができる。「好み」には任意の茶室 を好んだ人物を、写し」には物としての任意の茶室の名称がそれぞ

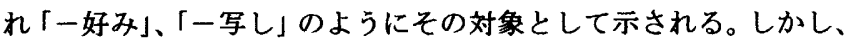

「好み」であること、「写し」であることそれぞれの境界線はあいま いである。例えば又隠や不蕃㸓などは、様々な写しのバリエーショ ンが存在し、写しであるかないかという境界は暧陎である。そのた め、ここでは嘉一郎が図面上に「一好小、「一曷」と直接に文字で明 記したもののみピックアップした。表 2 の〈茶室の形〉の欄中に「」 内に、嘉一郎の表記通りに表した「一好小「一翼」がそれである。 まず、表 2 にいくつか示したように、嘉一郎図面には「一好一鴌」
などの表記が見られ、嘉一郎にとって「好み」と「写し」の概念は 一つの茶室の中で共存していることがわかる。このことは，嘉一郎 が、物としての茶室と、それを好んだ人物との関倸性を強く意識し ていることを示すものであろう。

では、「好み」の対象人物、「写し」の対象茶空（本歌）はそれぞ れどのような特街を誈み取ることができるであろうか。以下に数量 的に考察する。茶室数全 242 室中、「好み」は 38 室、「写し」は 19

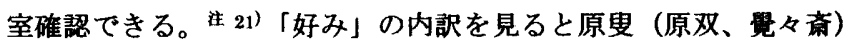
が 15 室でとびぬけて多く、遠州、如心意、啐榢斎が各 3 室で、利 休、有楽紊、吸江斎、即中斎が各 2 室で並ぶ。1 室のみ確認できる のは江岑、桑山、不昧、宗湛、不白、少庵、宗全である。「写し」は 残月亭が 7 室でとびぬけて多く、如庵、忘鉒、㟟庵がそれぞれ 2 室 で並ふ。1 室のみ確認できるのは山雲床、又隠、松風楼、庭玉軒で ある。また、茶室名でなく「遠州好薦」、「後水尾院御茶室葛」など と茶室名の記入がなく䍖」と表記されているものも確認できる。 なお、表記はなくとも又鿵、不審草、残月亭などの写しと思われる ものは多く、また、「一好」、「一写」の表記が見当たらなくとも、上 記に数えた表記されたものとほほ同じプランも多数含まれるため、 上記の数は更に多く見積もる必要がある。 
「好み」の対象となる人は、施主や設計者との関わりに左右され

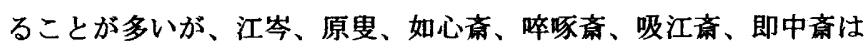
表千家の家元であり、不白や宗全も表千家との関わりが染い。全 38 室中 28 室という半数以上が表千家関連の人物の好みとなっている。 綍いて、「写し」の対象を見ても、残月亭、松風楼、㝨庵と、全 19 室中 10 室が表千家と特に関わりの梁い茶室で占められており、好 みと同様、表千家という流派の傾向をみることができる。

\section{5.まとめ}

以上、近・現代の茶室建策史において重きをなしたと考えられる 笛吹嘉一郎の、これまで把握されていない文献・図面史料、聞き取 り調査を通じてその職能の把握と建築作品の全体的把握を試みた。

嘉一郎の職能には大工棟梁としての木材加工や現場の指揮だけで なく、建築設計・製図も含まれていた。そして、その設計対象は、 住宅、茶室、庭、商業施設などが見られたが、茶の施設に専門性が 見られ、中でも特に大工仕事を中心的な対象とした設計であった。 このように、嘉一郎の設計対象の核として捉えられる茶室の設計内 容には「好み」や「写し」がそれぞれ 38 件、19件みられ、「好み」 や「写し」を実現できること自体一つの職能であることが示唆され る。そして、その「好外や「写し」の対象からは、表千家という 流派の傾向が見られたが、それは施主の傾向と同時に嘉一郎の職能 としての専門性を指摘することが出来よう。

嘉一郎の作品数 167 件という量、全国的な作品分布からは、以下 のことが示唆される。

近代における職人世界の变化は、株仲間の廃止と職業組合の誔生 注 22)、請負業者や建築家の参入による下部組織への再編入注 23) など が明らかにされている。それは、近世の職人世界に多く見られた出 入りと仲間の制度から自由になり、新たな枠組みの中での職人世界 の再構筮ではあったが、建築家に上部組織を奪われたものであった。 嘉一郎も、戦前はそのような営業の自由とともに、全国的に数多 くの茶室を手がけてきたと想定される。しかし、戦後は表千家家元 との結び付きが強くなり、いわゆる「出入り」注24)の数寄屋師とな る。建築世界において上記の再編入が加速する中、嘉一郎にとって 家元を中心とした職人世界は、建築家中心の近代建築界からの避難 場所であっただけでなく、「数寄屋師」として生きていく上での「厳 しさ」を追求できる場所であったと考えられる。そこには、職人世 界の人々が、自ら近代的な職人へと積極的に再構成していく中での、 「数㟢屋師」という職能が示唆されるだけでなく、当時進行してい た建築世界の「近代化」で見過ごされた職人たちのもう一つの「近 代」があったと捉えることができるのではないだろうか。中村博士 の言及する、建筑家でもなく数寄屋大工でもない「数奇屋師」の独 自性はこのあたりにあると思われる。嘉一郎の行動の軌跡とともに、 今後も考究したい。

以上、本稿では近・現代における茶窒の設計者として一つの柱と もなる笛吹嘉一郎の建策活動の輪郭を明らかにした。

謝辞 本研究は住宅総合研究財団の助成に多くを助けて頂きました。 そして、笛吹春子氏、吉村龍三氏、田尻晶英氏に多大な協力を頂き ました。記して謝意を表させて頂きます。
注

i 1) 松本康隆「3 代木津宗詮の職能と茶室の全体的把握のための基礶的研究」 『日本建築学会計画系論文集』第 602 号、191-198、2006.4。その他、木津宗 詮の茶室に関しては、松本康隆「大宮御所と秋泉亭」『日本建案学会大会学術 講演梗概集』9126、2005。

生2) 中村昌生『数奇の工匠』淡交社、1986

注3) 松本康隆・登根麻子「大河内山荘について」『日本建筑学会近㖪支部 研 究報告集』9045、2003

注 4) 松本康隆・吉田高子「雅俗山壮の茶空と茶会について 小林一三の茶室 に閣する研究その1」『日本建筑学会近幾支部研究報告集』9021、2000。 松本康隆・吉田高子「小林一三の茶室とその茶風」『日本建築学会大会学術辞 演梗概集』9061、2000。松本康隆・吉田高子「小林一三と笛吹嘉一郎の茶空

「福寿荘」『日本建築学会大会学術講演梗概集』9179、2001。

注5) 日向進 - 矢久崎善太郎・松本康隆「茶人木津宗詮と数㟢屋大工笛吹嘉一 郎による茶室の研究」『研究年報 No. 30』住宅研究財団、2004

清6) 日向他「茶人木津宗詮と数寄屋大工笛吹嘉一郎による茶室の研究」(注 5 に同じ)

注7) 笛吹春子氏（昭和 4 年生まれ）

住8）笛吹家過去狺より

注 9) 中村『数寄の工匠』(注 2 に同じ) によると、江戸時代末から明治にかけ て活瞿した平井家三代儀助は、みずから「数㟢屋師」を称していたらしい。

注 10) 凟料的裏づけは取れていないが、嘉三郎は、笛吹家の養子になり、笛吹 家を継ぐと同時に平井家のもとを離れたのではないかと考えられる。

住11) 田居亥之助 (M. 44-S. 57) の長男 (現：田尻工務店の代表)。亥之助は 4 代木津宗詮のもとで活躍した大工棟梁で、田尻工務店を立ち上げた。田尻工 務店所藏の「藤田御氏東邱茶室設計図」には「S. 29.9. 笛吹氏設計建築二依ル モ移築ノ為昭 49.3.12. 之 7 局ス 解体予定」とあり、藤田家の茶空移筮工事 を行う関係で、笛吹塐一郎図面を亥之助が描き写したものや実測図面と考え られるものが存在する。現時点で、田穴工務店所蔵図面に含まれる笛吹嘉一 郎関連のものは、これら旧藤田東邸の茶室図面 5 点のみ明らかであり、この 5 点を本稿で扱う図面史料に数える。

住 12)笛吹家所蔵の史料は建築図面を中心とした史料であるが、若干の茶道具 の図や茶会記、手紙や見積書なども含まれており、先の点数に入れている。 以下に分類方法について詳述する。

笛欥家所藏の図面史料は $\mathrm{A} 1$ サイズの木箱 2 つ、A2 サイズの木箱 2 つにそ れぞれ整理収納されたものや、整理されず丸めて、或いは折量まれているも の、いくつかの物件ごとに $\mathrm{A} 4$ サイズの封筒へ折り量まれて整理されているも のなどがある。

史料を筆者が整理する以前、どのように整理・使用・保存されていたのか、 また、以後の史料の紛失を明らかに出来るよう、まず、以下のように史料 1 点 1 点に番記号を付した。A1 サイズの木箱をそれぞれ(1)、(2)とし、当初の状 態がわかるよう、上から順に通し番号を付けた（1)-1～240、(2)-1〜 59)。 次に $\mathrm{A} 2$ サイズの木箱も同様に番号を付した（3－1〜73、(4)-1〜82）。複数 に丸められていた図面は、その単位がわかるようアルファベット a〜z、aa〜 ee を付した（5)ー1a〜187ee）。折り畕まれていた図面は木箱図面と同様に番 号を付した (6)-1〜52)。最後に、封筒に収納された図面は、笛吹家からお 厢りした順に(7)、(8)図面とし、封筒の単位ごとに(5)図面と同様のアルファベ ットを付した（一部封筒に入っていない図面も含んでいるが、それにはアル ファベットを付していない（(7)-1〜298u、(8)-1〜191p)。

上記の図面を以下の 7 つに分類した。7つのグループそれぞれに史料の点 数及び物件数を示したが、以下に表した史料の点数の合計が上記の計 1187 点 より少し多いのは、紙の裏表两面に描かれた図面史料が存在するためである。 以下の分類では 1 枚の図面でも、裹と表再面に描かれたものは、それぞれを 1 点と数える。また、今回数に入れた図面史料はほとんどが嘉一郎によるも のであるが、嘉一郎によるものか喻によるものか判別し難いもの、及び物件 名を同じくして䎁一郎図面と籍図面が混在して収納されているものがあった。 双方とも、物件として缞一郎が関わった可能性が高く、各物件の情報として まとめる整理の都合上、最後に分類した「短図面」には含めず、嘉一郎の物 件として取り扱うことにした。なお、分類は現時点で判別出来た上での分類 であり、今後の移動がありうる。物件数に関しても重複がある可能性がある。 「物件判明・年代判明」としたのは 867 点、104 件である。ここには図面上 に施主名もしくは物件名、或いはそれと思われる記載がなされ、かつ、年月 日が明記されているものを分別した。(一部、記载はないが、他の資料から判 別できたものも含む。以下同じ)

「物件名判明・年代不明」には 73 点、 42 件。ここには、物件名が記载され ているが、年代が記載されていないものを分類した。

「物件名不明・年代判明」には15 点、14 件。物件名が記截されていないが、 年代が記載されているものを分類した。

「物件名不明 - 年代不明 - 地域判明」には 6 点、6 件。物件名、年代とも記 载されず、不明であるが、「和歌山市某家茶室設計図」、台彎某氏茶室設計図」 なと地域名だけ判別できるものを分類した。

「不明物件」は 103 点、83 件。物件名、年代、地城とも不明な、一つの完結 した物件や部分的な建築図面をここに分別した。

「その他」としたのは 114 点。「高松宮殿邱離御殿平面図」や「清水谷御数寄 屋古図二依儿平面図」、立䣓基子設計図」、頋収書」など、明らかに嘉一郎 作品でない建築図面や、嘉一郎の作図や記述であるが茶道具や領収書など、 建築図面以外のものをここに含めた。

「敉図面」は 56 点、21 件。ここには、蔽単独の仕事と考えられるものを含 
めた。嘉一郎と同時期のものや時期的には勀一郎歿後であるが同物件（増改 築などのため) と考えられるものは、物件別の整理の都合上、嘉一郎図面の ものの中に含めている。また、ここに分類して明記した以上に蓆図面は多数 存在するが、現時点では榐図面単独で整理されているものを史料数に入れて いない。

注 13) 日向他「茶人木津宗詮と数㟢屋大工笛吹素一郎による茶室の研究」(注 5 に同じ)

注 14) 春子氏によると、西尾真とは、表千家家元の信任䕗い、茶道教授とのこ と。生形貴一は表千家茶道教授で、小林一三をはじめ、関西の著名な数寄者 を数多く弟子にもった人物。そして、徳禅寺和尚とは、故大亀老師とのこと であった。

注 15) 春子氏によれば、西尾真のもとで 15 歳の時から茶道の嵇古をはじめて いたとのことである。

注 16) 春子氏の記憶によると、自䄮茶室「無孔庵」は、自邱内の仕事場の移転 に伴い、空いたスペースに建てた茶室とのこと。そして、その仕事場の移転 について、資料的裹付けはとれていないが、春子氏が閏いている記憶による と、昭和 2 年頃らしい。また、茶会の亭主は嘉一郎、亭主の補佐に嘉一郎の 妹、水屋には嘉一郎の茶道の師である西尾真に入ってもらい、嘉一郎夫人は 料理人の補佐をしていたとのこと。

注 17) 後に、諪一郎の設計によって「洞零庵」が建てられるとともに、会の名 称も「洞雲会」となったとのこと。

注 18) 松文商店の元常務。大正 15 年生まれ。

生 19）表には左端加ら、〈番号〉、〈現状〉、〈物件名〉、〈建築年〉、〈設計者〉、〈所 在地〉、〈設計内容〉、〈茶室の形〉、〈図面通し番号・典拠〉の欄を設けた。〈現 状〉には、存在を確認できたものに「有」、取り壤されたものに「無」と記入 した。〈物件名〉に泩件の名前を記入し、著名人など補足的な説明を（）内 に記入した。〈建築年〉は判明する限り記入し、図面上に複数年の記述が確認
できる場合は設計・施工期間と考えそのまま複数年を記入した。所在地〉は 判明する限り都道府県と市町村名を記入した。所在地情報が全くないものは 「不明」とし、情報量が少しあるがピンポイントで判明しないものについて は、情報が書かれた当時と地名が変更している場合もあるので情報源の表記 のまま記入し、「(不詳)」と付した。〈設計内容〉には判明する限りであるが、

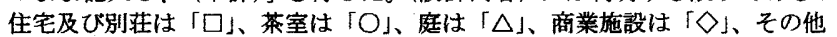
もしくは不明なものは「メ」で表記した。〈茶室の形〉には、「で確認で きる茶室の数を把握できるようにし、続いて茶室の形を略記した。図面通し 番号・典挻〉には、図面があればまず図面を、そしてその他の史料などを記 載した。なお、現時点では図面史料の分類と同様、物件の重複記載は避けら れない。

注20) 図面史料の情報が断片的なだけでなく、例えば岡田孝男『茶室平面集』 学芸出版社、H. 4 の情報は茶室の略平面図のみとなる。

注 21)「利休三拈大目茶席」と表記されていて「利休好み」であると想定され るもの、「残月亭」とのみ表記されていて「残月亭写し」であると想定される ものなどは表 2 中に「利休小、「残月亭」などと表記したが、「好」及び「鴌」 の文字が確認できないため、ここで数えた「好み」「写し」の数には入れて いない。また、著名な茶室と形態的に似ていて「写し」であると想定される ものも、「好」及び「藏」の文字が確認できなければ数に入れていない。

注22）西和夫『工匠たちの知恵と工夫一建築技術史の散歩みち』彰国社、1980 注 23) 初田亭『職人たちの西洋建築』筑摩書房、2002

注 24) 中村『数前の工匠』(前掲注 2) にも「特に表千家との接触が密となり、 やがて世間からは表千家の専属のごとくみられるようになった」と述べられ ており、一般的に表千家の「出入り」であるという認識があったと考えられ る。

（2006年 1 月 10 日原稿受理，2006年 9 月 1 日採用決定 